\title{
Analysis of Fijis Regional Trade Using Gravity Model
}

\author{
Nakisha Natasha Bi, Ximei Kong* \\ School of Business, Zhengzhou University, Zhengzhou, China \\ Email: binakisha@hotmail.com, ${ }^{\star}$ kongximei@126.com
}

How to cite this paper: Bi, N. N., \& Kong, X. (2022). Analysis of Fijis Regional Trade Using Gravity Model. Open Journal of Business and Management, 10, 17-38. https://doi.org/10.4236/ojbm.2022.101002

Received: October 26, 2021

Accepted: December 14, 2021

Published: December 17, 2021

Copyright $\odot 2022$ by author(s) and Scientific Research Publishing Inc. This work is licensed under the Creative Commons Attribution International License (CC BY 4.0).

http://creativecommons.org/licenses/by/4.0/ (c) (i) Open Access

\begin{abstract}
Regional trade is equally important for countries as international trade. The Pacific Islands Forum Secretariat (PIFS) is the body that facilitates regional trade in the Pacific by implementing and upholding free trade agreements between its member countries. This paper looks at the trade agreements that Fiji is part of and determines the export levels of commodities trade with its regional partners. Fiji's export in 2019 totals $\$ 1,032,914.40$ (US thousand) of which approximately forty-one percent $(40.85 \%)$ is exported to regional countries. Its leading export commodity to regional countries in 2019 includes food products and fuel worth $\$ 72,228.62$ (US thousand) and $\$ 70,818.74$ (US thousand) respectively.
\end{abstract}

\section{Keywords}

Regional Trade, Exports, Trade Agreements, Pacific Forum Island Trade Secretariat (PIFS), Gravity Model of Trade

\section{Introduction}

Fiji is one of the most developed countries economically in the Pacific region. With a population close to 900,000 , and gross domestic product of 4.38 billion USD in 2020 (Trading Economics, 2021), Fiji is ranked as one of the most developing countries amongst the Pacific Islands Forum Secretariat (PIFS) countries. Pacific Islands Forum Secretariat is an organization which looks after the regional political and economic policies. It was initiated in 1971 and was originally named the South Pacific Forum (SPF) but was later renamed in 1999. Cook Island and six other sovereign nations met in Wellington to start this organization as these small island states of the Pacific became afresh independent, with an expectation that more nations would join as colonial presence was fading away. It currently has eighteen members which include Australia, Cook Islands, 
Federated States of Micronesia, Fiji, French Polynesia, Kiribati, Nauru, New Caledonia, New Zealand, Niue, Palau, Papua New Guinea, Republic of Marshall Islands, Samoa, Solomon Islands, Tonga, Tuvalu, and Vanuatu.

Fiji heavily relies on the tourism industry in terms of economic growth and is the largest source of foreign income and foreign investment, followed by agriculture sector, which used to be the backbone of Fiji, however in recent years the tourism industry has taken over. In 2018 tourism sector contributes 30\% towards the GDP employing around 119,000 Fijians whereas agriculture sector contributes 8\% towards GDP (Investment Fiji, 2021). Other sectors include manufacturing sector ( $12.3 \%$ of GDP), fisheries ( $1.8 \%$ of GDP), forestry $(0.75 \%$ of GDP), Information, Communication and Technology (ICT), energy sector, health sector, mining and groundwater sector, and audio visual sector (Investment Fiji, 2021).

Most of Fiji's regional export partners are members of the Pacific Islands Forum Secretariat (PIFS). Fiji export commodities include fuel, including oil, fish, beverages, gems, sugar, garments, gold, timber, fish, molasses, coconut oil, mineral water whereas import commodities include manufactured goods, machinery and transport equipment, petroleum products, food and beverages, chemicals, tobacco. Fiji's major trading partners in terms of exports include US 20.8\%, Australia 14.9\%, NZ 7.7\%, Tonga 5\%, Vanuatu 4.6\%, China 4.5\%, Spain $4.3 \%$, UK 4.3\%, Kiribati 4.1\% (2017) and major import partners include Australia 19.2\%, NZ 17.2\%, Singapore 17\%, China 13.8\% (2017) (Global Finance Magazine, 2019). The scope of this paper focuses on the level of exports that Fiji engages in with its regional partners.

PIFSs main vision is to achieve regional peace, harmony, security, promote social inclusion and prosperity so that all Pacific individuals can spearhead unrestricted, healthy and productive lives. In order to achieve all these, the forum encourages collaboration amongst member governments and with international agencies by representing the welfare of its members (Asian Development Bank \& Asian Development Bank Institute, 2015). Since its formation the forum has always worked towards achieving its vision. The PIFS holds annual meetings where dialogue partners are included in order for the member countries to become open minded in decision making. These dialogue partners include Canada, People's Republic of China, Cuba, European Union, France, Germany, India, Indonesia, Italy, Japan, Republic of Korea, Malaysia, Philippines, Spain, Thailand, Turkey, the United Kingdom and the United States. Apart from this the forum also has observers to oversee the decisions made which include American Samoa, Guam, Northern Mariana Islands, Timor-Leste, Wallis \& Futuna, United Nations, Asian Development Bank, Commonwealth of Nations, Western and Central Pacific Fisheries Commission (WCPFC) and the World Bank.

Fiji joined PIFS in 1971; however, Fiji was suspended from the PIFS in 2009 following the failure of conducting elections and a return to democracy after the 2006 military take-over of the government. The event marked Fiji to be the first 
country to be suspended from the Forum since its existence. The Forum had earlier warned Fiji in August 2008 to conduct the general election and democratically elect the government before the given deadline of May 1, 2009. Upon failure to fulfill the promise made by the interim Military regime to return to democracy, the Forum suspended Fiji's membership on May 2, 2009. The Forum declared Fiji as a regime which had contempt for basic human rights, democracy and freedom. Fiji remained suspended until the return to constitutional democracy through free and fair elections on September 14, 2009 and welcomed again into PIFS on October 22, 2009.

Fiji's first trading began within the Pacific region in the 19th century with sandalwood and beach-de-mer. In the 1860s most European settlers came to Fiji to establish cotton plantations after the price boom of cotton due to American Civil War. Thus, cotton became the 1st export commodity for Fiji under the British colony. Once the cotton demand was phasing out following the end of the civil war, the first Governor of the British Colony Sir Author Gordon introduced Indian indentured labour system in 1874 with negation with the Australian Colonial Sugar Refining Company in order to inaugurate sugar plantations and processing mills. Fiji began to export sugar to Australia (which was also under the British Colony) in 1874 making sugar as second trade commodity and Australia as the first trading partner. Fiji became independent from Britain in 1970 and later joined PIFS in 1971 which sowed seed for trading with other member countries. European Union (EU) became Fiji's largest export market post-independence for sugar under the preferential trade agreement Lomé Convention which expired in 2000. Upon the phasing out of the Lomé Convention, the export price for sugar began to drop forcing Fiji to undergo structural changes in the sugar industry. Demand for garment industry and tourism further reduced the importance of the sugar industry in Fiji. The garment industry had been very fruitful for Fiji with preferential trading agreements with Australia and New Zealand. Later bottled mineral water (Fiji Water) became another important export industry in Fiji. Currently tourism is the largest service trading industry in Fiji.

This paper looks at the trade agreements that Fiji is part of and determines the export levels of commodities trade with its regional partners. The scope of the paper is confined to analysis using the gravity model for estimation method. The dependent variable in our analysis was log of total regional trade measured in constant US dollar value. The independent variables used were GDP, population size, geographical distance and exchange rate. The new contribution this paper makes is to the body of literature available in Fiji on regional trade. Previous research using the ARMAX model has been done by Narayan, Narayan, and Chand Prasad (2008) however the focus has been broadly on international trade. The current research paper focuses on regional trade and more specifically on the regional trade partners under the Pacific Islands Forum Secretariat (PIFS).

The paper is structured using six sections and each section serves its own 
purpose. Section one introduces the readers to Fiji's industries and the commodities that are exported regionally. It then describes Fiji's position in the Pacific Forum Island Secretariat (PIFS), the establishment of PIFS and the trade agreements that it facilitates for its member countries. Section two examines several literatures relevant to the study and identifies the gaps that the current study is filling through research. Section three outlines the methodology adopted for the research while section four serves as the context section elaborating on the various regional trade agreement. Section five is results and discussion chapter which guides the main evidences derived from the data collected and analyzed which is concluded in the final conclusion section of the paper.

\section{Literature Review}

For developing nations, commercial trade is affected by factors such as natural resources, labour, policies and most importantly by globalization. Due to high demand, countries compete with each other and this high competition often results in developing nations losing the battle to developed nations. Therefore, they rely on the regional export partners for the niche market. Usually, regional partners are attached to trade agreements that cushion the impacts of losing markets for the products in the developing nations. Regional Trade Agreements (RTA) implicate the way in which individual entities as well as business entities produce, consume and exchange goods and services (Singh, Chand, Gounder, \& Paul, 2018). RTAs allow the partners to engage in free trade of goods and services which may be costly to produce in their own countries. Thus, this engagement allows countries like Fiji greater regional economic integration. Singh et al. (2018) made valuable contributions towards the already lacking body of knowledge on RTAs and its impact on exporting businesses in Fiji. However, there is still a lack of knowledge among the businesses on the export markets of Fiji's product. Therefore, this paper contributes to this knowledge gap.

The Regional Trade Agreements (RTAs) aim to reduce trade barriers among trading partners and make sure that it is done in the way most preferential to the trading partners (Jugurnath, Stewart, \& Brooks, 2007). However, there is a constant debate that RTAs facilitate free trade among member countries but reduce trade with the non-member countries. Trade creation occurs when RTAs increase total trade and trade diversion results when countries engage in trade with non-members. Freund and Ornelas (2010) argue that trade trends toward regionalism could be damaging the external trade liberalization and multilateral trading systems in the long run. RTAs include provisions for investment and migration; therefore, liberalization of foreign investment and migration will promote trade creation or trade intended towards regional partners (Rodrik, 2018). Consequently, the regional trade agreements become a closed bloc that discourages multilateralism and distorts the pattern of international trade (MacPhee \& Sattayanuwat, 2014).

Regionalism in the Pacific has been significantly successful in promoting co- 
operation and integration in other sectors apart from trade. The University of the South Pacific is truly a regional educational institution owned by twelve Pacific Island countries (Naidu, 2019). Its campuses spread across the member countries and are considered as one of the remarkable educational providers for the Pacific people. Pacific leaders have begun perceiving themselves as strong and resilient people closely linked shared values, traditional practices and spiritual connections (Searight, Harding, \& Tran, 2019). They have also come together to redefine the regions security priorities with emphasis on cyber security, human trafficking and climate change (Goulding, 2015).

Narayan, Narayan, and Chand Prasad (2008) use the autoregressive moving average with explanatory variables (ARMAX) model to forecast Fiji's exports and imports for the period between 2003 and 2020. They reveal that forecasts of international trade have vital policy implications. It can assist the state to deduce the trade deficits, conclusively allowing the state to gauge the sustainability of the economy's current account deficit. Other stakeholders can use this crucial information such as the policy makers to question the current monetary and fiscal policy stance in turn leading to policy amendments. Investors also see the potential in an economy as forecasts determine the future status of an economy. Results of the study (Narayan et al., 2008), show that Fiji's imports will outperform exports over 2003 to 2020 mainly because of Fiji's poor export performance. Therefore, the current study provides an analysis on the actual level of regional exports from Fiji to further support or negate the claims made by $\mathrm{Na}$ rayan et al. (2008).

The current research paper fills the analytical gap by providing the analysis using gravity model for the estimation method. It contrasts gravity model as another applicable model to estimate the total regional trade and the various independent variables or factors that influence or has significant effect on Fiji's regional trade with the PIFS co-members. Regional trade had been rendered less attention by researchers and has been widely ignored as potentials to Gross Domestic Product. This paper focuses on regional trade to fill the literature gap which is useful for researchers, academic and the state for policy formulation.

\section{Methodology}

This study employs secondary data analysis. Existing data sets were accessed on the World Integrated Trade Solution (WITS) which is a trade software provided by the World Bank for anyone who requires access to relevant international trade databases. Users can summarize trade statistics by country on total exports, imports, export-import partners, top products exported or imported, exporters and importers around the globe and generate customized statistics as per required. The trade data for Fiji was accessed which was divided into four sections; country profile, trade indicators, trading partners and top exported products. From the trading partners section, only the regional partners under the PIFS were selected and statistics on exports from 2009 to 2018 of these partners 
were retrieved from WITS. Graphs were drawn for analysis.

The second stage of analysis was through the use of gravity model for estimation method. The dependent variable in our analysis was log of total regional trade measured in constant US dollar value. The independent variables used were GDP, population size, geographical distance and exchange rate. The GDP is measured in constant US dollar value. The population of the country is measured as the number of people living in the nations. The geographical distance is measured in kilometers while the exchange rate was measured in US dollar value. The log values were calculated for each of the independent variables using E-views software to estimate the total regional trade for Fiji and how the independent variables which are the economic indicators have an effect on the total regional trade.

\section{Regional Trade Agreements}

\subsection{The Pacific Island Countries Trade Agreement (PICTA)}

This agreement was signed on August 18, 2001 by 14 countries namely: Cook Islands, Federated States of Micronesia (FSM), Fiji, Kiribati, Nauru, Niue, Republic of Marshall Islands (RMI), Palau, PNG, Samoa, Solomon Islands, Tonga, Tuvalu and Vanuatu and only open to countries which fall under Pacific territories. The original agreement was regarding free trade of goods (excluding trade of alcohol, tobacco products and government procurement rules) amongst the member countries, later in 2008 it was expanded and now caters for trade of services as well. The goods traded under this agreement should have a composition of at least $40 \%$ local content.

The main objective of this agreement are as follows: 1) strengthen, expand and diversify trade between the Parties; 2) promote and facilitate this expansion and diversification through the elimination of tariff and non-tariff barriers to trade between the Parties in a gradual and progressive manner, under an agreed timetable, and with a minimum of disruption; 3) develop trade between the Parties under conditions of fair competition; 4) promote and facilitate commercial, industrial, agricultural and technical cooperation between the Parties; 5) further the development and use of the resources of the Pacific region with a view to the eventual creation of a single regional market among the Pacific Island economies in accordance with the respective social and economic objectives of the Parties, including the advancement of indigenous peoples; and 6) contribute to the harmonious development and expansion of world trade in goods and services and to the progressive removal of barriers to it (Pacific Island Countries Trade Agreement (PICTA), 2011).

PICTA involved gradually reducing tariffs over a period of ten years which was extended till 2017 and later extended till 2021. This included member countries to remove all non-tariff barriers (quotas, import and export licenses etc.) and prohibits them from intending lower tariff rates to non-PICTA countries than what is offered to member countries. 


\subsection{The Melanesian Spearhead Group Trade Agreement (MSGTA)}

The Melanesian Spearhead Group (MSG) formed in 1986 is one of the three sub-regional groups (other two are Micronesians and Polynesians ${ }^{1}$ ) in the Pacific. It comprises the Melanesian countries of the South West Pacific namely Fiji, Papua New Guinea (PNG), Solomon Islands and Vanuatu. The Melanesian countries are inhabited by the vast majority of the regional population and the economies mostly driven by tourism and agriculture (Lawson, 2013). In 1993, PNG, Solomon Islands and Vanuatu signed the Melanesian Spearhead Group Trade Agreement (MSGTA). Fiji joined the MSG in 1996 and joined the MSGTA in 1998 noting the importance the trade agreement had on cultural, historical, political and trade in the region. Front de Liberation the Nationale Kanak et Socialiste (FLNKS) of New Caledonia joined the MSG in 1989. FLNKS is a pro-independence treaty of political parties in New Caledonia founded in 1984 as a legislative body of several political parties. Majority of its supporters are mostly from the Kanak indigenous population but also include supporters from other ethnic communities (Somare, 2015).

The establishment of the MSGTA is an indicator of effective regional relationships and a landmark indicator of success for the MSG. In 2004 the MSG members decided to upgrade the agreement and to include a negative list approach to tariff liberalization in its place of the prior mode of trading on a positive list. The intention for the new approach to tariff liberalization would be less restrictive, as members of the agreement would list the commodities on which tariffs are to be sustained, commodities on which no cutbacks in tariff will be applied (May, 2011). This new trade agreement was called MSGTA2 and was signed by the four countries in 2005 . The trade agreement was noted to be the most operative agreement since 2011 after under the chairmanship of Josaia Voreqe Bainimarama, the Prime Minister of Fiji.

MSG region is a fundamental part of Fiji's overall trade, investment and economic policies and strategies, hence inclusion of trade in services, investments and labour mobility has further deepened and integrated Fiji's trade in the MSG region. Since 2017 the MSG has been working on finalizing the new MSGTA3, the paperwork is still underworking at the moment with two members already signed. Once the agreement has been ratified by all members of the MSG, it will replace the MSGTA2-2005.

The MSG looks into five major aspects: 1) observe political and security developments and inform on concerns to safeguard a persistent and peaceful Melanesia, 2) deliver trade and Investment policy related advice to members and develop and implement the Trade Investments \& Economic Development ${ }^{1}$ The Pacific people were characterized into three distinct groups namely Melanesian, Polynesian and Micronesians. Historically, the three groups were uniquely different in appearance, culture, social structures and language. Polynesia meant many islands, Micronesia meant small island literally referring to geographic factors and land size, but Melanesia was more ethnically defined as "black islands" mainly referring to the colour of the inhabitants as the "black race of Oceania" (Lawson, 2013). 
(TIED) related programmes, 3) empower the MSG to cooperate in climate change, environmental sustainability, and natural resources management, 4) organize events, develop and implement the sports programme in the MSG region, and 5) create an empowering environment to fortify the attachment that binds Melanesian's composed arts and culture.

\subsection{The Interim Economic Partnership Agreement (IEPA)}

The Interim Economic Partnership Agreement is collaboration between the Pacific countries (Fiji and PNG) and the European Union (EU). This engagement is largely to overcome the market disturbances in export. The agreement allows duty free and quota free market access to a variety of Fijian products to EU countries. Sugar and rice are excluded from this agreement because they are subjected to longer transitional periods.

IEPA regulations facilitate the investors in the fisheries industry to export fish caught in Fiji using global boats provided it is processed in Fiji. The IEPA partners are still in the process of negotiating a comprehensive agreement to deepen trade relations between them.

\subsection{The South Pacific Regional Trade and Economic Cooperation Agreement (SPARTECA)}

The agreement was signed in 1980 by government of Australia, New Zealand and other pacific island countries including the Cook Islands, Fiji, Kiribati, Nauru, Niue, Papua New Guinea, Solomon Islands, Tonga, Tuvalu and Western Samoa with following objectives: 1) to achieve progressively in favor of Forum Island countries duty free and unrestricted access to the markets of Australia and New Zealand over as wide a range of products as possible; 2) to accelerate the development of the Forum Island countries in particular through the expansion and diversification of their exports to Australia and New Zealand; 3) to promote and facilitate this expansion and diversification through the elimination of trade barriers; 4) to foster the growth and expansion of exports of Forum Island countries through the promotion of investment in those countries; 5) to promote greater penetration by exports from Forum Island countries into the Australian and New Zealand markets through such measures as cooperation in the marketing and promotion of goods from Forum Island countries; and 6) to promote and facilitate economic cooperation, including commercial, industrial, agricultural and technical cooperation (South Pacific Regional Trade and Economic Cooperation Agreement (SPARTECA), 1980).

SPARTECA is a non-reciprocal agreement that allows Fiji and other Forum Island Countries (FICs) to export almost all of their products to Australia and New Zealand duty free. Fiji also benefits from the SPARTECA-TCF Scheme which allows its textiles, clothing and footwear (except wool and wool blend fabrics) to be exported to Australia duty free under more favourable rules of origin. 


\subsection{The Pacific Agreement on Closer Economic Relations (PACER)}

Signed on August 18, 2001 the Pacific Agreement on Closer Economic Relations (PACER) serves as an agreement between members of the Pacific Islands Forum (member countries with Australia and New Zealand) which offers an arrangement for the future development of trade and economic relations amongst member countries. PACER is similar to PICTA with the inclusion of Australia \& New Zealand.

The main objective of this agreement strengthens, expands and diversifies trade between the participating countries. the main objectives then was as follows: 1) to provide a framework for cooperation leading over time to the development of a single regional market; 2) to foster increased economic opportunities and competitiveness through more effective regional trade arrangements; 3 ) to minimize any disruptive effects and adjustment costs to the economies of the Forum Island Countries, including through the provision of assistance and support for the Forum Island Countries to undertake the necessary structural and economic adjustments for integration into the international economy; 4) to provide economic and technical assistance to the Forum Island Countries in order to assist them in implementing trade liberalization and economic integration and in securing the benefits from liberalization and integration; and 5) to be consistent with the obligations of any of the Parties under the Marrakesh Agreement Establishing the World Trade Organization (Pacific Agreement on Closer Economic Relations (PACER), 2018).

PACER not only arranges for programmes of assistance to the member countries with trade facilitation and capacity building. But also presages forthcoming negotiations on Forum-wide reciprocal free trade which includes Australia and New Zealand. The PACER was modified and renamed as PACER PLUS in 2017, the agreement now covers goods, services, investment, labour, sanitary and phytosanitary (SPS) measures, aid and other issues, brings to a close eight years of negotiations between Australia, New Zealand (Pacific Agreement on Closer Economic Relations (PACER), 2018). PACER Plus replaces the earlier SPARTECA agreement giving Australia and New Zealand preferential access to goods, services and investments. With the agenda of development assistance and labour mobility, seasonal workers from the island member countries are employed in various sectors in Australia and New Zealand. PACER PLUS was signed by Australia, New Zealand and 8 Pacific Island Countries: the Cool Islands, Kiribati, Nauru, Niue, Samoa, the Solomon Islands, Tonga and Tuvalu on June 14, 2017. Fiji and PNG are yet to sign the PACER Plus agreement.

\subsection{Commonwealth Free Trade Agreement}

Amongst the 53 members the following 12 Pacific Island Countries are part of Commonwealth free trade: Australia, New Zealand, Papua New Guinea, Fiji, Solomon Island, Samoa, Vanuatu, Tonga, Cook Islands, Kiribati, Nauru, Tuvalu. Commonwealth free trade is a proposal to establish free trade amongst member 
countries. However most countries have grouped themselves into the following five regional integration; ASEAN, European Union, Caribbean Community, Southern African Customs Union, East African Community, and the South Asian Association for Regional Cooperation unfortunately this regional integration excludes Pacific Island countries.

\section{Data Analysis and Discussion}

Table 1 provides detailed Fiji's export share percentage by regional trade partners. The table arranges the regional partners from the highest export share percentage to the least export share percentage according to the average export share for the period of ten years (2010 to 2019). The findings indicate that Australia is the major regional export partner for Fiji followed by New Zealand and Tonga. One of the main reasons as to why Australia has the highest export share is because Australia is the major buyer of Fijian gold. The SPARTECA allows Fiji's textiles and clothing to enter the Australian markets. Moreover, most former Fijians have migrated to Australia and New Zealand, thus prefer to consume Fijian food products and vegetables. Food products and vegetables are the two major commodities exported to New Zealand and are the third most commodity exported to Australia. The three countries where Fiji's products are exported the

Table 1. Fiji's export share percentage by regional partners.

\begin{tabular}{|c|c|c|c|c|c|c|c|c|c|c|c|}
\hline & 2010 & 2011 & 2012 & 2013 & 2014 & 2015 & 2016 & 2017 & 2018 & 2019 & Average \\
\hline Australia & 52.04 & 42.56 & 38.54 & 32.69 & 28.61 & 34.44 & 35.03 & 41.02 & 30.70 & 31.29 & 36.69 \\
\hline New Zealand & 14.39 & 13.60 & 11.81 & 12.84 & 11.76 & 10.61 & 16.39 & 18.22 & 15.58 & 17.82 & 14.30 \\
\hline Tonga & 7.39 & 12.76 & 11.80 & 12.39 & 9.96 & 11.83 & 9.84 & 0.00 & 11.90 & 14.00 & 10.19 \\
\hline Vanuatu & 5.34 & 4.79 & 5.20 & 6.13 & 6.06 & 7.57 & 9.80 & 8.88 & 6.95 & 6.88 & 6.76 \\
\hline Kiribati & 3.87 & 4.76 & 5.66 & 9.64 & 8.37 & 8.94 & 7.91 & 6.69 & 4.38 & 4.43 & 6.47 \\
\hline Samoa & 4.72 & 4.82 & 4.38 & 4.99 & 6.39 & 5.34 & 5.71 & 6.40 & 5.57 & 6.50 & 5.48 \\
\hline Papua New Guinea & 2.93 & 4.40 & 8.75 & 7.40 & 4.31 & 4.69 & 4.31 & 2.56 & 5.44 & 2.89 & 4.77 \\
\hline Tuvalu & 2.20 & 2.15 & 1.79 & 2.27 & 8.72 & 2.41 & 2.26 & 2.95 & 5.00 & 3.71 & 3.35 \\
\hline Cook Islands & 1.98 & 3.79 & 4.02 & 1.41 & 2.93 & 3.07 & 2.61 & 3.60 & 3.46 & 4.94 & 3.18 \\
\hline Niue & 1.79 & 1.97 & 2.81 & 2.97 & 3.55 & 2.74 & 2.92 & 3.63 & 2.86 & 2.77 & 2.80 \\
\hline Solomon Islands & 1.79 & 1.97 & 2.81 & 2.97 & 3.55 & 2.74 & 2.92 & 3.63 & 2.86 & 2.77 & 2.80 \\
\hline Nauru & 0.50 & 1.74 & 1.80 & 3.04 & 6.15 & 4.93 & 0.96 & 1.26 & 1.26 & 0.83 & 2.25 \\
\hline New Caledonia & 1.16 & 1.23 & 2.12 & 3.02 & 1.96 & 2.15 & 0.88 & 2.48 & 3.52 & 1.73 & 2.03 \\
\hline French Polynesia & 1.44 & 1.05 & 1.10 & 0.95 & 0.88 & 0.91 & 1.05 & 1.75 & 2.87 & 1.35 & 1.33 \\
\hline Micronesia, Fed. Sts. & 0.59 & 0.44 & 0.43 & 0.44 & 0.36 & 0.51 & 0.51 & 0.56 & 0.46 & 0.48 & 0.48 \\
\hline Marshall Islands & 0.20 & 0.29 & 0.13 & 0.18 & 0.28 & 0.31 & 0.21 & 0.44 & 0.35 & 0.69 & 0.31 \\
\hline Palau & 0.01 & 0.01 & 0.01 & 0.00 & 0.01 & 0.01 & 0.01 & 0.01 & 0.02 & 0.01 & 0.01 \\
\hline
\end{tabular}

Source: World Bank, 2021, https://wits.worldbank.org. 
least are Federated States of Micronesia, Marshall Islands and Palau. These three countries are administered by the United States of America therefore it is likely American products are highly promoted and consumed.

Fiji is blessed with abundance of natural and mineral resources with the exception of the extensively used mineral product: petroleum. Although Fiji is investing in biofuels to achieve sustainable development, the local production is not sufficient to meet the domestic demand thus; fuel is imported from Singapore, Korea, Australia and the United Arab Emirates. Being the hub of the South Pacific, it not only engages in importing fuel but re-exporting to other Pacific Island Countries (PICS).

According to data presented in Figure 1, Tonga is the major importer of Fiji's re-exported fuel followed by Cook Islands, Kiribati, Nauru, and New Caledonia. Food products (Table 2) is Fiji's major export commodity for the period between 2010 to 2019. Sugar, biscuits, flour, mineral water, molasses, cocoa, canned fish, snacks, kava, tobacco, concentrated juice and alcohol are some of the food products exported by Fiji to its regional partners. Next major commodity exported from Fiji is stones and glass. Australia made up $13.79 \%$ (95\% percent of total stone and glass were exported to Australia from the period of 2010 to 2019) of the total average percentage of $14.51 \%$ for stone and glass, and the remaining $0.72 \%$ is exported to other regional countries. Textiles and clothing is the third major commodity

Table 2. Fiji's export percentage to regional country by products.

\begin{tabular}{|c|c|c|c|c|c|c|c|c|c|c|c|}
\hline & 2010 & 2011 & 2012 & 2013 & 2014 & 2015 & 2016 & 2017 & 2018 & 2019 & Average \\
\hline Fuels & 7.75 & 17.11 & 19.37 & 21.57 & 21.50 & 20.26 & 11.83 & 5.51 & 14.49 & 16.22 & 15.56 \\
\hline Food Products & 14.71 & 15.76 & 16.85 & 16.00 & 12.73 & 12.92 & 12.30 & 17.81 & 19.51 & 16.54 & 15.51 \\
\hline Stone and Glass & 23.00 & 18.81 & 16.19 & 9.62 & 8.99 & 12.27 & 15.36 & 17.29 & 12.04 & 11.58 & 14.51 \\
\hline Textiles and Clothing & 17.34 & 11.97 & 11.90 & 13.50 & 11.59 & 14.59 & 13.43 & 13.37 & 11.78 & 11.73 & 13.12 \\
\hline Vegetable & 9.81 & 8.46 & 8.00 & 8.45 & 7.60 & 9.29 & 9.17 & 6.55 & 5.82 & 6.20 & 7.93 \\
\hline Mach and Elec & 3.23 & 4.14 & 4.55 & 5.41 & 12.54 & 5.05 & 7.51 & 11.26 & 9.44 & 11.82 & 7.49 \\
\hline Metals & 6.34 & 6.59 & 6.36 & 6.62 & 6.47 & 5.47 & 6.64 & 6.58 & 6.09 & 6.78 & 6.39 \\
\hline Chemicals & 5.47 & 5.27 & 5.20 & 5.84 & 5.23 & 5.73 & 5.47 & 5.96 & 5.90 & 5.96 & 5.60 \\
\hline Wood & 4.32 & 3.64 & 3.67 & 3.46 & 3.93 & 3.37 & 3.56 & 4.06 & 3.10 & 3.32 & 3.64 \\
\hline Miscellaneous & 1.60 & 1.48 & 1.76 & 2.40 & 2.31 & 2.01 & 4.28 & 2.76 & 2.71 & 2.42 & 2.37 \\
\hline Animal & 2.66 & 3.18 & 2.21 & 1.91 & 1.58 & 1.89 & 2.50 & 1.91 & 1.75 & 1.83 & 2.14 \\
\hline Transportation & 1.26 & 1.27 & 1.31 & 2.03 & 1.79 & 1.83 & 2.72 & 2.49 & 2.70 & 2.72 & 2.01 \\
\hline Minerals & 1.09 & 0.82 & 1.20 & 1.15 & 1.74 & 3.37 & 3.03 & 2.26 & 2.91 & 1.16 & 1.87 \\
\hline Plastic or Rubber & 1.01 & 1.16 & 0.92 & 1.36 & 1.40 & 1.46 & 1.70 & 1.63 & 1.39 & 1.44 & 1.35 \\
\hline Footwear & 0.34 & 0.30 & 0.43 & 0.60 & 0.50 & 0.41 & 0.39 & 0.40 & 0.25 & 0.20 & 0.38 \\
\hline Hides and Skins & 0.08 & 0.06 & 0.09 & 0.09 & 0.09 & 0.10 & 0.13 & 0.15 & 0.12 & 0.10 & 0.10 \\
\hline
\end{tabular}

Source: World Bank, 2021, https://wits.worldbank.org. 


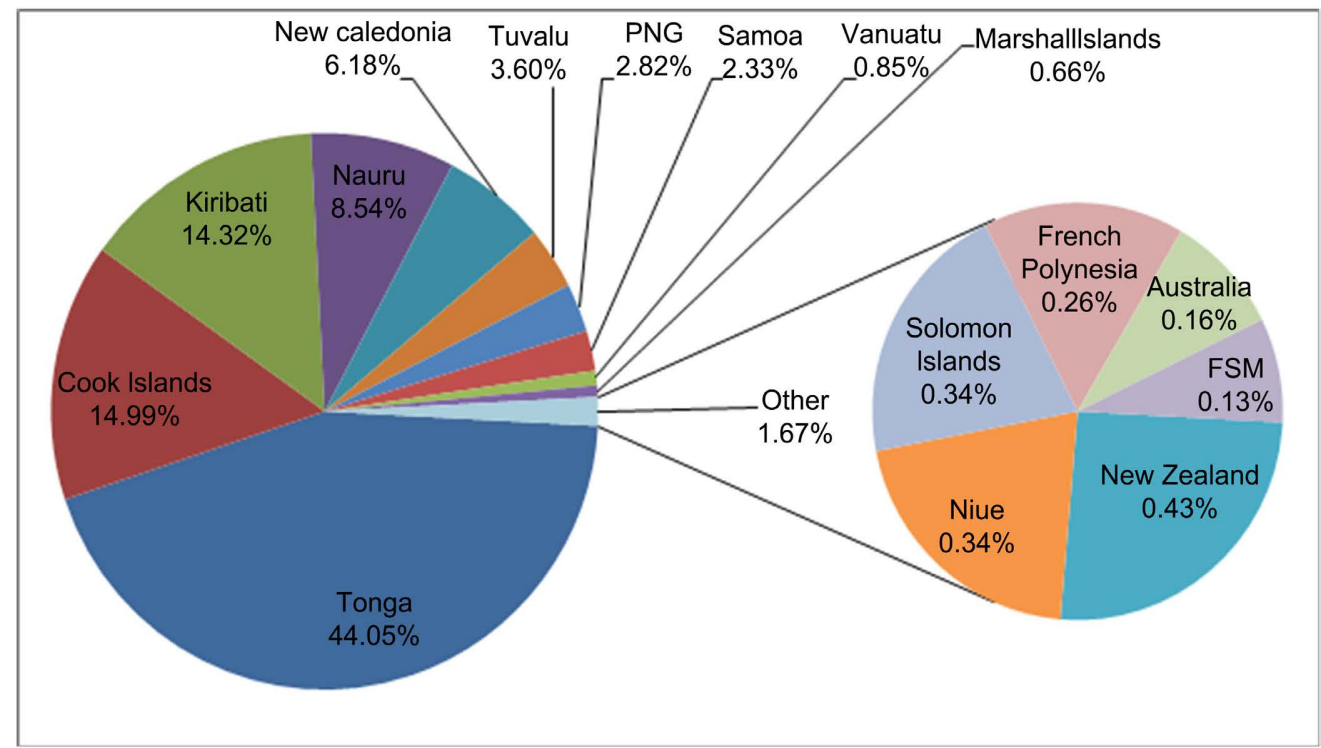

Figure 1. Average percentage fuel re-exported to regional countries from 2010-2019. Source: World Bank, 2021, https://wits.worldbank.org.

exported to regional countries. Minerals, plastic or rubber, footwear and hides and skins are the least exported products from Fiji to the region.

\subsection{PIFS Economic Indicators}

Regional trade is one of the important tools for increase in trade. Developing trade relationships with regional countries has led to an increase in trade flows between partner countries in the last twenty years. In developing countries such as Fiji, trade agreements help the governments to identify the relevant policies which could allow several opportunities for trade. RTAs enable a country to present higher levels of labour skills, environment, transparency, accountability that will eventually help in the formation of progressive reforms and future trade agreements. Regardless of the advantages that RTAs have on partner countries, there are concerns on the sovereignty, commitment and flexibility of each agreement.

There are many underlying factors that affect trade between the countries as well as RTAs. These include but are not limited to change in weather conditions (natural disasters such as drought, cyclones, tsunami, etc.), global prices fluctuation, political instability, domestic issues (land disputes, migration, labour shortage, etc.), exchange rate, and devaluation of dollar and countries openness. Consequently, these underlying factors have an impact on the GDP of the countries.

According to Table 3, Australia has the highest GDP of all the Pacific Island Forum Secretariat countries, significantly higher than all the other six countries that initiated the Forum. Even though fluctuation is seen in the GDP of Australia, it remains the nation with the highest GDP from 2010 to 2017. Fiji, Vanuatu 
Table 3. PIFS nations GDP (constant US\$ million) 2010-2017.

\begin{tabular}{|c|c|c|c|c|c|c|c|c|}
\hline Country Name & 2010 & 2011 & 2012 & 2013 & 2014 & 2015 & 2016 & 2017 \\
\hline Australia & $1,146,140$ & $1,396,650$ & $1,546,150$ & $1,576,180$ & $1,467,480$ & $1,351,690$ & $1,208,850$ & $1,329,190$ \\
\hline Fiji & 3141 & 3775 & 3972 & 4190 & 4857 & 4683 & 4930 & 5353 \\
\hline Kiribati & 156 & 182 & 190 & 185 & 180 & 171 & 178 & 187 \\
\hline Micronesia, Fed. Sts. & 297 & 311 & 327 & 317 & 319 & 316 & 332 & 367 \\
\hline New Zealand & 146,619 & 168,510 & 176,248 & 190,846 & 200,922 & 177,468 & 188,224 & 205,416 \\
\hline Palau & 186 & 197 & 212 & 221 & 242 & 280 & 295 & 286 \\
\hline Papua New Guinea & 14,251 & 17,985 & 21,296 & 21,261 & 23,211 & 21,724 & 20,759 & 22,743 \\
\hline Samoa & 663 & 737 & 761 & 770 & 757 & 788 & 799 & 832 \\
\hline Solomon Islands & 847 & 1050 & 1191 & 1285 & 1336 & 1307 & 1379 & 1484 \\
\hline Tonga & 367 & 415 & 471 & 451 & 440 & 437 & 421 & 460 \\
\hline Tuvalu & 32 & 39 & 38 & 38 & 37 & 35 & 37 & 41 \\
\hline Vanuatu & 701 & 792 & 782 & 802 & 815 & 760 & 804 & 880 \\
\hline
\end{tabular}

Source: World Bank, 2021, https://wits.worldbank.org.

and New Zealand have experienced GDP increases from the previous years throughout the period with the exception in 2015. Palau for one had a GDP increase every year for the same period. All other countries experienced fluctuations. The GDP of the other regional partners could not be accessed.

Both Australia and New Zealand have significantly higher per capita incomes in comparison to other PIFS nations as depicted in Table 4. They are both more than thrice and twice respectively to the next highest nation, Palau. It is interesting to note that PNG, which has a higher GDP than Fiji, scores lower in GDP per capita. Kiribati scores the lowest in the GDP per capita for all nations whose data was accessible. French Polynesia, New Caledonia, Nauru, Cook Island, Niue, Marshall Islands data on GDP and GDP per capita was not available.

Figure 2 shows the annual population growth rate of PIFS nation in 2019. While the world population growth rate annually stands at $1.1 \%$ for the same period, the majority of Fiji's regional trade partners' annual population growth rate exceeds the world rate. This means that the regional partners are growing in population faster than the world. The higher population growth rate indicates a large and growing market for products.

Table 5 shows the geographical distance in kilometers from Fiji's capital, Suva to the capital cities of PIFS nations. When geographical distances increase, it directly affects the cost of transportation; hence there is a negative effect on trade.

Table 6 provides an overview of descriptive statistics such as mean, median, maximum, minimum, standard deviation, skewness and the number of occurrences for the main variables (total tarde, population, exchange rate, distance and population) used in the study. 
Table 4. PIFS nations GDP per Capita (constant US\$ Thousands).

\begin{tabular}{ccccccccc}
\hline Country Name & 2010 & 2011 & 2012 & 2013 & 2014 & 2015 & 2016 & 2017 \\
\hline Australia & 52.0 & 62.5 & 68.0 & 68.2 & 62.5 & 56.8 & 50.0 & 54.0 \\
Fiji & 3.7 & 4.4 & 4.6 & 4.8 & 5.6 & 5.4 & 5.7 & 6.1 \\
Kiribati & 1.5 & 1.7 & 1.8 & 1.7 & 1.6 & 1.5 & 1.6 & 1.6 \\
Micronesia, Fed. Sts. & 2.9 & 3.0 & 3.1 & 3.0 & 3.0 & 2.9 & 3.0 & 3.3 \\
New Zealand & 33.7 & 38.4 & 40.0 & 43.0 & 44.5 & 38.5 & 39.9 & 42.7 \\
Palau & 10.4 & 11.1 & 12.0 & 12.6 & 13.7 & 15.9 & 16.6 & 16.1 \\
Papua New Guinea & 1.9 & 2.4 & 2.8 & 2.7 & 2.9 & 2.7 & 2.5 & 2.7 \\
Samoa & 3.6 & 3.9 & 4.0 & 4.0 & 3.9 & 4.1 & 4.1 & 4.3 \\
Solomon Islands & 1.6 & 1.9 & 2.1 & 2.2 & 2.3 & 2.2 & 2.2 & 2.3 \\
Tonga & 3.5 & 4.0 & 4.6 & 4.4 & 4.4 & 4.3 & 4.2 & 4.5 \\
Tuvalu & 3.0 & 3.6 & 3.5 & 3.5 & 3.4 & 3.2 & 3.3 & 3.6 \\
Vanuatu & 3.0 & 3.3 & 3.1 & 3.1 & 3.1 & 2.8 & 2.9 & 3.1 \\
\hline
\end{tabular}

Source: World Bank, 2021, https://wits.worldbank.org.

Table 5. Distance in kilometers of PIFS nations from Fiji.

\begin{tabular}{cc}
\hline Country & Distance from Suva, Fiji $(\mathrm{Km})$ \\
\hline Australia & 3455 \\
Kiribati & 2147 \\
Micronesia, Fed. Sts. & 4114 \\
New Zealand & 2595 \\
Palau & 5534 \\
Papua New Guinea & 3909 \\
Samoa & 1139 \\
Solomon Islands & 2129 \\
Tonga & 804 \\
Tuvalu & 1179 \\
Vanuatu & 1211 \\
\hline
\end{tabular}

Table 6. Descriptive statistics of the main variables.

\begin{tabular}{cccccc}
\hline & Total Trade & GDP & Distance & Exchange Rate & Population \\
\hline Mean & $111,422.7$ & $1.45 \mathrm{E}+11$ & 2703.700 & 11.97763 & $3,705,754$. \\
Median & $22,696.84$ & $6.95 \mathrm{E}+08$ & 2371.000 & 1.580000 & $215,787.0$ \\
Maximum & $622,066.5$ & $1.38 \mathrm{E}+12$ & 5534.000 & 108.9900 & $24,601,860$ \\
Minimum & 0.000000 & $1.56 \mathrm{E}+08$ & 804.0000 & 0.970000 & $17,603.00$ \\
Std. Dev. & $192,473.8$ & $3.79 \mathrm{E}+11$ & 1456.684 & 29.50910 & $703,6243$. \\
Skewness & 1.645392 & 2.609489 & 0.437698 & 2.677069 & 2.141997 \\
\hline
\end{tabular}




\begin{tabular}{cccccc} 
Continued & \multicolumn{7}{c}{} \\
\hline Kurtosis & 3.986758 & 8.000130 & 2.157790 & 8.279509 & 6.280679 \\
Jarque-Bera & 39.34318 & 174.1301 & 4.918793 & 188.4667 & 97.05156 \\
Probability & 0.000000 & 0.000000 & 0.085487 & 0.000000 & 0.000000 \\
Sum & $8,913,813$. & $1.16 \mathrm{E}+13$ & $216,296.0$ & 958.2100 & $2.96 \mathrm{E}+08$ \\
Sum Sq. Dev. & $2.93 \mathrm{E}+12$ & $1.14 \mathrm{E}+25$ & $1.68 \mathrm{E}+08$ & $68,792.15$ & $3.91 \mathrm{E}+15$ \\
Observations & 80 & 80 & 80 & 80 & 80 \\
\hline
\end{tabular}

Source: Authors Estimation.

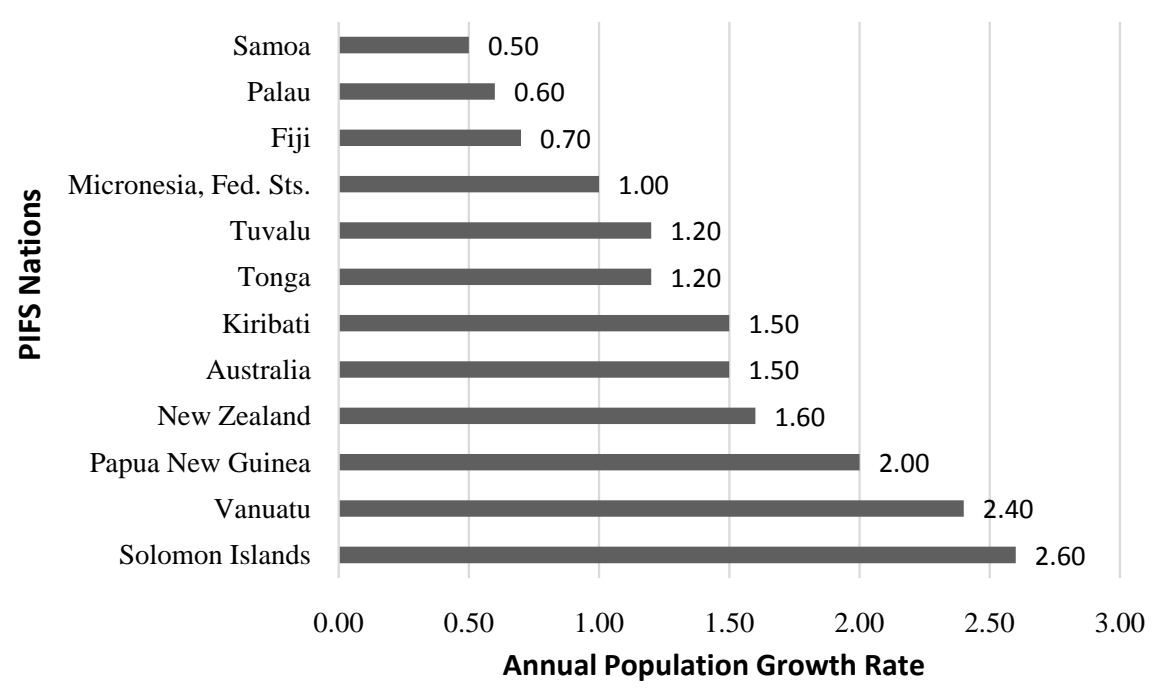

Figure 2. PIFS Nations annual population growth rate (2019). Source: World Bank, 2021, https://wits.worldbank.org.

\subsection{Gravity Model}

To understand the nature of trade in this era of globalization, economists have often utilized the gravity model. The model originated in 1962 by Jan Tinbergen who stated that trade flows between two countries can be measured by the gravity equation derived from Newton's law of gravitation (Van Bergeijk \& Brakman, 2010; Genc, 2014; Pietrzak \& Lapinska, 2015). According to Newton's universal law of gravitation, gravitational attraction between two objects is proportional of their masses and inversely related to square of their distance as shown in the formulae below:

Equation (1):

$$
F_{i j}=G \frac{M_{i} M_{j}}{D_{i j}^{2}}
$$

where:

$F_{i j}$ is the gravitational attractions

$M_{i}, M_{j}$ are the masses of two objects

$D_{i j}$ is the distance

$G$ is the gravitational constant 
Timbergen used a gravity model to analyze foreign trade whereby he used GDP and geographical distance as independent variables to calculate trade which is the dependent variable. The results showed that the GDP variable has positive effect on trade flow contradictory to distance. He concluded that countries with higher GDP and closer in distance have a higher probability of trading with each other (Ristanovic, Primorac, \& Kozina, 2020). Tinbergen's model of trade flow using gravity model is shown below:

Equation (2):

$$
T_{i j}=A \frac{Y_{i} Y_{j}}{D_{i j}^{2}}
$$

where:

$T_{i j}$ means total trade flow from origin country $i$ to destination country $j$

$Y_{i}, Y_{j}$ are the size of the economy for the two countries $i$ and $j . Y_{i}, Y_{j}$ can be either gross domestic product (GDP) or gross domestic product per capita (PGDP)

$D_{i j}$ is the distance between country $i$ and $j$

while $A$ is a constant term

Gravity model has been adopted to explain regional trade between Fiji and the PIFS nations in this study. Similar study was carried by (Binh, Duong, \& Cuong, 2013), to analyze bilateral trade activities of Vietnam using variables GDP, population, distance, exchange rate, culture and strategic partner. This model was also used by Ram and Prasad (2007) to measure Fiji's global trade potential using GDP, distance, synchronization cost, transaction cost and cultural distance. For the purpose of this study, the above model is further extended with the incorporation of variables GDP (constant), distance, population size and exchange rate. Therefore, the gravity model in logarithmic form for this study is presented below:

Equation (3):

$$
\begin{aligned}
\log T_{i j t}= & \alpha_{0}+\alpha_{1} \log \left(Y_{i t}\right)+\alpha_{2} \log \left(Y_{j t}\right)+\alpha_{3} \log \left(N_{i t}\right) \\
& +\alpha_{4} \log \left(N_{j t}\right)+\alpha_{5} \log D_{i j}+\alpha_{6} E X_{i j t}+e_{i j t}
\end{aligned}
$$

where:

$i=1$ (original country-Fiji)

$j=1,2,3,4 \ldots$ (other PIFS countries)

$t=$ year $(2010,2011,2012 \ldots 2017)$

$T_{i j i}$ : Fiji's trade with country $j$ in year $t$

$Y_{i t}$. Fiji's GDP in year $t$

$Y_{j:}$ country $j \mathrm{GDP}$ in year $t$

$N_{i t}$ Fiji's population in year $t$

$N_{j i}$ country $j$ population in year $t$

$D_{i j}$ : distance between Fiji and country $j$ in kilometers

$E X_{i j t:}$ exchange rate between Fiji and country $j$ in year $t$

$e_{i j i}$ error term 
Table 7 presents the estimations' results of the gravity model approached in Equation (3) above. The variables which have influence on Fijis regional trade are GDP of both Fiji and partner country $\left(Y_{i t}, Y_{j t}\right)$ and distance between Fiji and Partner country $\left(D_{i j}\right)$ because they have significant coefficient, whereas exchange rate $\left(E X_{i j t}\right)$ and population of Fiji and partner countries $\left(N_{i t}, N_{j t}\right)$ seem to have no impact on regional trade because of insignificant coefficient values. The growth in GDP of Fiji and partner countries will increase the total trade value between them. The estimated coefficient of these two variables is statistically significant and show positive correlation. An increase of $1 \%$ in GDP of both countries will enhance total trade value by approximately $0.65 \%$. Geographical distance is statistically significant and estimated to decrease total regional trade between Fiji and partner countries, when distance increases by $1 \%$ the total trade value is estimated to decrease by $3.47 \%$ on average. Exchange rate has negative coefficient and the effect of this variable on regional trade is also insignificant. If the population of the two countries increase by $1 \%$, regional trade value will also increase by approximately $0.21 \%$, however the effect of this variable on regional trade is insignificant.

Pearson product-moment correlations coefficient gives values between -1 and +1 which is used to demonstrate correlation between variables at continuous levels. A positive relationship is indicated between two variables if the value is positive, while a negative relationship is denoted if the value is negative. A value closer to +1 signifies stronger positive relationship while values closer to -1 signify stronger negative relationship. When both variables increase and both variables decrease at the same time a positive relationship is formed. If one variable increases and the other decreases a negative relationship is formed.

According to Table 8 GDP has positive correlation with total trade (0.63), population (0.93) and distance (0.25). While there is a stronger positive correlation between GDP and total trade, and, GDP and population, a weaker positive correlation is noted between GDP and distance. There is a weak positive correlation between population and distance (0.17). Exchange rate has weak negative correlations with all other variables except for total trade which has weak positive. Population has a stronger positive correlation (0.65) with total trade, while distance has a stronger negative correlation with total trade $(-0.15)$.

Table 7. Gravity model estimates.

\begin{tabular}{ccccc}
\hline Variable & Coefficient & Std. Error & t-Statistic & Prob. \\
\hline C & 19.59098 & 1.884675 & 10.39489 & $0.0000^{\star}$ \\
EXCHANGE_RATE & -0.004467 & 0.004594 & -0.972328 & $0.3341^{\star}$ \\
LGDP & 0.648045 & 0.121221 & 5.345963 & $0.0000^{*}$ \\
LPOPULATION & 0.208713 & 0.160319 & 1.301862 & $0.1970^{\star}$ \\
LDISTANCE & -3.467121 & 0.235744 & -14.70712 & $0.0000^{*}$ \\
\hline
\end{tabular}

Note: ${ }^{\star} p=0.05$; Source: Authors Estimation. 
Table 8. Correlations.

\begin{tabular}{cccccc}
\hline & Total Trade & GDP & Population & Distance & Exchange Rate \\
\hline Total Trade & 1.000000 & & & & \\
GDP & 0.630904 & 1.000000 & & & \\
Population & 0.652197 & 0.930996 & 1.000000 & & \\
Distance & -0.500102 & 0.249401 & 0.166689 & 1.000000 & \\
Exchange Rate & 0.114182 & -0.147894 & -0.086767 & -0.382010 & 1.000000 \\
\hline
\end{tabular}

Source: Authors Estimation.

Table 9. Robust check.

Dependent Variable: LTR Method: Robust Least SquaresDate: 11/07/21 Time: 16:26

Sample: 196

Included observations: 79 Method: M-estimation

M settings: weight $=$ Bisquare, tuning $=4.685$, scale $=$ MAD (mediancentered)

Huber Type I Standard Errors \& Covariance

\begin{tabular}{|c|c|c|c|c|}
\hline Variable & Coefficient & Std. Error & z-Statistic & Prob. \\
\hline $\mathrm{C}$ & 15.02243 & 1.073998 & 13.98739 & $0.0000^{*}$ \\
\hline LPOPULATION & -0.105997 & 0.088971 & -1.191363 & $0.2335^{\star}$ \\
\hline LEXCHANGE_RATE & 0.125221 & 0.058325 & 2.146942 & $0.0318^{*}$ \\
\hline LDISTANCE & -3.373381 & 0.129245 & -26.10062 & $0.0000^{*}$ \\
\hline LGDP & 0.990199 & 0.067056 & 14.76678 & $0.0000^{*}$ \\
\hline \multicolumn{5}{|c|}{ Robust Statistics } \\
\hline R-squared & 0.645925 & \multicolumn{2}{|c|}{ Adjusted R-squared } & 0.626786 \\
\hline Rw-squared & 0.974795 & \multicolumn{2}{|c|}{ Adjust Rw-squared } & 0.974795 \\
\hline Akaike info criterion & 114.1370 & \multicolumn{2}{|c|}{ Schwarz criterion } & 129.7417 \\
\hline Deviance & 38.70709 & \multicolumn{2}{|c|}{ Scale } & 0.598957 \\
\hline \multirow[t]{2}{*}{ Rn-squared statistic } & 2019.039 & \multicolumn{2}{|c|}{ Prob(Rn-squared stat.) } & 0.000000 \\
\hline & \multicolumn{3}{|c|}{ Non-robust Statistics } & \\
\hline Mean dependent var & 9.411399 & \multicolumn{2}{|c|}{ S.D. dependent var } & 2.918605 \\
\hline S.E. of regression & 1.279604 & \multicolumn{2}{|c|}{ Sum squared resid } & 121.1667 \\
\hline
\end{tabular}

Note: ${ }^{\star} p=0.05$.

A correlation coefficient which has a value of zero indicates null or no relationship between the variables. According to gravity model shown in Table 7 , exchange rate has negative coefficient and the effect of this variable on regional trade is insignificant. In Table 8 similar results are shown whereby the coefficient value between exchange rate and total trade is closer to zero indicating insignificance or no relationship.

Table 9 provides the robust check for the main variables (population, exchange rate, distance and population) with the dependent variable trade. The 
robust regression was performed with the M-Estimation for values to generate the above table. According to table, the exchange rate, distance and GDP are significant to regional trade since it yielded $p$-values $\left(0.0318^{\star}, 0.0^{\star}, 0.0^{\star}\right.$ respectively) of less than 0.05 . Population however is not significant as the p-value $\left(0.2335^{\star}\right)$ is more than 0.05 . Similar results were shown in the gravity model estimation except for exchange rate which was not significant. This draws on to the Adjusted R-squared value (0.067) which shows that the independent variables are robust measures for the dependent variable in this study. Adjusted $\mathrm{R}$-squared is a modified version of R-squared that has been adjusted for the number of predictors in the model. Typically, the adjusted R-squared is always positive and lower than the R-squared. A value more than 0.5 and closer to 1 indicates higher robustness of the variables used in the study, thus the variables in the current study are adequately robust.

\section{Conclusion}

For a developing country like Fiji, trading regionally is as important as trading with countries outside the region. Fiji's participation in regional trade is facilitated by regional trade agreements namely, PICTA, PACER, MSGTA, IEPA, SPARTECA, Commonwealth Free Trade Agreement. Fiji's regional trade partners are Australia, Cook Islands, The Federated States of Micronesia, French Polynesia, Kiribati, Nauru, New Caledonia, New Zealand, Niue, Palau, Papua New Guinea, Republic of Marshall Islands, Samoa, Solomon Islands, Tonga, Tuvalu, and Vanuatu. The scope of this paper was limited to the discussion on Fiji's major regional trade partners, major commodities exported and the economic indicators such as GDP, population, distance between the two countries and exchange rate. The variables were then analyzed using the gravity model to understand the nature of regional trade that Fiji engages in.

Australia and New Zealand are the two major importers of Fiji products. A large proportion of Fiji's re-exports relates to the distribution of petroleum for shipping and airlines. Cook Islands, the federated States of Micronesia, Nauru, Papua New Guinea and Tonga's major import from Fiji is fuel while countries such as French Polynesia, Kiribati, New Caledonia, Niue, Solomon Islands and Vanuatu import food products as the major commodity from Fiji. Stones and glass are largely imported by Australia. New Zealand's largest imports from Fiji are metals while Palau and Samoa's largest import commodity from Fiji is chemicals. Marshall Islands and Tuvalu's major imports are vegetables and minerals respectively.

Fiji's export in 2019 totals $\$ 1,032,914.40$ (US thousand) of which approximately forty-one percent (40.84\%) is exported to regional countries. Its leading export commodity to regional countries in 2019 includes food products and fuel worth $\$ 72,228.62$ (US thousand) and $\$ 70,818.74$ (US thousand) respectively. Fiji exports animals, food products, and footwear to Vanuatu more than any other regional country. Most of Fiji's stones and glass, hides and skins, textiles and 
clothing, machine and electronics, and miscellaneous exports go to Australia. The largest amount of vegetables, metals and transportations is exported to New Zealand from Fiji. Majority of chemicals and plastic or rubber are exported to Samoa while bulk of the minerals, fuel, and wood are exported to Tuvalu, Tonga, and Solomon Islands respectively.

Findings also indicate that trade relations between Fiji and regional countries improved significantly from 2014. These improvements can be attributed to the fact that: 1) Fiji was reinstated to PIFS after return to democracy following the 2014 general election; 2) the newly elected government was determined to achieve economic growth and re-establishing trade relations within regional networks. Policies of future regional governments will determine trade relations among them and how they can work together to continue with the ongoing trade agreements as well as future agreements. Further research is required to analyze the impact of COVID-19 on regional trade with member countries of the PIFS.

The analysis through gravity model indicates the effects of the economic indicators (GDP, population, distance between two countries, and exchange rate) on the total regional trade. As GDP and population increase, the total regional trade also increases and vice-versa. Distance has negative impact on total trade whereby an increase in the distance between the two countries will reduce the level of trade; countries will trade with those countries nearer to them. However there is no impact of exchange rate on the total trade value because the demand and supply of a product remain unchanged regardless of fluctuation in exchange rate. In summation, a developing country such as Fiji needs to identify the economic indicators required to enhance regional trade. Trade will lead to an increase in revenue, consequently resulting in facilitating the needs and wants of the population.

\section{Conflicts of Interest}

The authors declare no conflicts of interest regarding the publication of this paper.

\section{References}

Asian Development Bank, \& Asian Development Bank Institute (2015). Pacific Opportunities: Leveraging Asias's Growth. In Asian Development Bank \& Asian Development Bank Institute (Eds.), Pacific Opportunities (pp. 87-101). Asian Development Bank.

https://www.adb.org/sites/default/files/publication/161895/adbi-pacific-leveraging-asia s-growth.pdf

Binh, D. T. B., Duong, N. V., \& Cuong, H. M. (2013). Applying Gravity Model to Analyze Trade Activities of Vietnam. Forum for Research in Empirical International Trade.

Freund, C., \& Ornelas, E. (2010). Regional Trade Agreements. Annual Review of Economics, 2, 139-166. http://www.jstor.org/stable/42940326 https://doi.org/10.1146/annurev.economics.102308.124455

Genc, M. (2014). A Gravity Model of Barriers to Trade in New Zealand. The Treasury. 
Global Finance Magazine (2019). Fiji GDP and Economic Data. Classeditori. https://www.gfmag.com/global-data/country-data/fiji-gdp-country-report

Goulding, N. (2015). Marshalling a Pacific Response to Climate Change. In G. Fry, \& S. Tarte (Eds.), The New Pacific Diplomacy (pp. 191-204). Australian National University Press. https://doi.org/10.22459/NPD.12.2015.16

Investment Fiji. (2021). Tourism. https://www.investmentfiji.org.fj/pages.cfm/for-investors/sector-industry-profiles/touri sm.html

Jugurnath, B., Stewart, M., \& Brooks, R. (2007). Asia/Pacific Regional Trade Agreements: An Empirical Study. Journal of Asian Economics, 18, 974-987. https://doi.org/10.1016/j.asieco.2007.09.003

Lawson, S. (2013). 'Melanesia': The History and Politics of an Idea. The Journal of Pacific History, 48, 1-22. http://www.jstor.org/stable/41999457 https://doi.org/10.1080/00223344.2012.760839

MacPhee, C. R., \& Sattayanuwat, W. (2014). Consequence of Regional Trade Agreements to Developing Countries. Journal of Economic Integration, 29, 64-94.

http://www.jstor.org/stable/23819362 https://doi.org/10.11130/jei.2014.29.1.64

May, R. (2011). The Melanesian Spearhead Group testing Pacific Island Solidarity. Australian Strategic Policy Institute. http://www.jstor.org/stable/resrep03975

Naidu, V. (2019). A Commentary on the 50-Year History of the University of the South Pacific. In S. Firth \& V. Naidu (Eds.), Understanding Oceania (pp. 11-34). Australian National University Press. https://doi.org/10.22459/UO.2019.02

Narayan, P. K., Narayan, S., \& Chand Prasad, B. (2008). Forecasting Fiji's Exports and Imports, 2003-2020. International Journal of Social Economics, 35, 1005-1016. https://doi.org/10.1108/03068290810911516

Pacific Agreement on Closer Economic Relations (PACER) (2018).

Pacific Island Countries Trade Agreement (PICTA) (2011).

Pietrzak, M. B., \& Lapinska, J. (2015). Determinants of the European Union's Trade-Evidence from a Panel Estimation of the Gravity Model. E+M Ekonomie a Management, 18, 18-27. https://doi.org/10.15240/tul/001/2015-1-002

Ram, Y., \& Prasad, B. C. (2007). Assessing Fiji's Global Trade Potential Using the Gravity Model Approach. School of Economics, University of the South Pacific.

Ristanovic, V., Primorac, D., \& Kozina, G. (2020). Applying Gravity Model to Analyse Trade Direction. Tehnički vjesnik, 27, 1670-1677. https://doi.org/10.17559/TV-20200217101315

Rodrik, D. (2018). What Do Trade Agreements Really Do? The Journal of Economic Perspectives, 32, 73-90. http://www.jstor.org/stable/26409425 https://doi.org/10.1257/jep.32.2.73

Searight, A., Harding, B., \& Tran, K. M. (2019). Pacific Regionalism and Regional Architecture. In Strengthening the U.S.-Pacific Islands Partnership (pp. 8-12). Center for Strategic and International Studies (CSIS). http://www.jstor.org/stable/resrep22579.5

Singh, G., Chand, M., Gounder, N., \& Paul, J. (2018). Regional Trade Agreements and Their Impact on Export Firms. Australasian Journal of Regional Studies, 24, 237-255.

Somare, M. (2015). Melanesian Spearhead Group: The Last 25 Years. In G. Fry, \& S. Tarte (Eds.), The New Pacific Diplomacy (pp. 291-298). Australian National University Press.

South Pacific Regional Trade and Economic Cooperation Agreement (SPARTECA) (1980). 
Trading Economics (2021). Fiji GDP. https://tradingeconomics.com/fiji/gdp

Van Bergeijk, P. A. G., \& Brakman, S. (2010). The Gravity Model in International Trade: Advances and Applications. Cambridge University Press.

https://doi.org/10.1017/CBO9780511762109 